\title{
Experiencing Transnationalism at Home: Open Borders and the \\ Everyday Narratives of Non-Migrants
}

\author{
Katherine Tonkiss
}

Accepted for publication in Politics

\section{Introduction}

A rich normative literature exploring the defensibility of controls on migration across borders, and arguing in favour of more extensive international migration rights, has grown in size and strength over recent decades. This literature has predominantly stemmed from Joseph Carens' seminal essay on freedom of movement (Carens, 1987; see also Carens, 2013; Cole, 2000; Risse, 2008; Rubio-Marin, 2000; Seglow, 2005; Verlinden, 2010). The growth of this literature has coincided with a rapid acceleration of the practice of international migration, with some heralding an 'age of migration' at the beginning of the $21^{\text {st }}$ century (Castles and Miller, 2009). The extent to which the migration rights literature has engaged with the situated experience of migration practices is, however, very limited, with particularly little attention paid to the experience of migration 'at home'; that is, for those living in receiving localities where experiences are local and relatively fixed; or to the narrative methodologies which could facilitate this perspective.

This article seeks to address this gap directly, by highlighting the value of research into everyday, lived experiences of international migration practices for theorising migration rights. Specifically, the article advances the methodological argument that exploring everyday narratives of migration provides insights into the ways in which obstacles to the full realisation of migration rights are constructed in everyday life, which can in turn support the development of more robust open borders theory. This argument is extended 
through the examination of an illustrative example of research into the everyday narratives of migration specifically among non-migrants ${ }^{i}$ in the county of Herefordshire, England.

The research presented offers insights into how, in this particular micro-level context, non-migrants shaped experiences of migration in their local community as a result of their 'banal' national loyalty, and as a result constrained the full realisation of migration rights in this setting. For open borders theory, then, the research indicates that it may be problematic for theorists to pursue arguments in favour of freedom of movement without addressing the challenges that nationalism raises for the realisation of such migration rights head on. This suggests that theorists should accompany accounts of open borders with theories of post-national forms of integration which reframe citizenship and belonging with reference to universal human rights rather than to national belonging. In drawing on this example the article demonstrates how everyday narratives research can support normative theorising about migration rights, which in itself supports a broader argument in favour of bridging the gap between normative theorising and qualitative research into everyday experience.

After first discussing the migration rights literature with a particular focus on the work of Joseph Carens, the article explores emerging scholarship which is beginning to incorporate more empirical research into normative theorising and then introduces the research into non-migrant narratives in England and provides an overview of the research design. It then gives a brief discussion of the main findings of this illustrative research and their implications for migration rights theory, before finally concluding with some methodological reflections the value of this approach.

\section{Theorising Open Borders}


A rich seam of scholarship has problematized the idea that liberal nation-states have a right to control who may or may not enter a territory, on the basis that a commitment to liberal equality is inconsistent with controls on migration. The cornerstone of this literature is Joseph Carens' seminal argument in favour of open borders (1987; 2013). Specifically, Carens draws on the work of John Rawls to argue that, in the hypothetical 'original position' where individuals decide on principles of justice from behind a 'veil of ignorance' which disguises 'accidents of natural endowment' (Rawls, 1999 [1979], p.14) - in other words, the morally arbitrary characteristics of individuals which should have no bearing on justice - place of birth and nationality should be considered as morally arbitrary characteristics. This is because, Carens argues, they are unchosen but have significant consequences for individuals' access to wealth and opportunities. The 'luck' of birth in an affluent nation carries with it significant advantages over birth in a poorer country (see also Schachar, 2009).

As a result, Carens suggests that individuals in the original position would select the right to migrate as a basic liberty, on the grounds that to not permit migration would hinder liberty on morally arbitrary grounds and would perpetuate morally arbitrary inequalities. This would contravene Rawls' two core principles of justice, which are first, that 'each person is to have an equal right to the most extensive scheme of equal basic liberties compatible with a similar scheme of liberties for others', and second, that 'social and economic inequalities are to be arranged so that they are both (a) reasonably expected to be to everyone's advantage, and (b) attached to positions and offices open to all' (Rawls, 1999 [1979], p.53). Restrictions on migration, Caren argues, do not allow for equal basic liberties and perpetuate inequalities by not permitting people to migrate for work and better opportunities (Carens, 1987; see also 2013, ch.11). 
These arguments are pursued at length in the wider literature on freedom of movement, where unrestricted migration is tied intrinsically to the expression of the moral equality of all individuals, as per the first principle of justice (Cole, 2000; Dummett, 2004; Verlinden, 2010), and claims that states have a right to democratically decide on their own border control fail to account for the moral equality of all individuals, regardless of their membership status, in participating in such a democratic process (Abizadeh, 2008; RubioMarin, 2000). In the absence of any morally significant reason to distinguish between individuals on the basis of place of birth, restricting migration becomes an infringement of liberty on a par with restricting movement within the state. Further, restrictions on migration are argued to be instrumental in overcoming inequalities in wealth and resources, the imperative for which emerges from a recognition of the moral equality of all individuals, and as per the second principle of justice. For example, Risse (2008) argues for migration rights to be tied to access to natural resources which, he supposes, are owned by all in common on the basis of individual moral equality. Seglow (2005) argues in favour of unrestricted migration until a basic standard of a 'decent life' is attained by all.

Such accounts of open borders, while focused on normative theorising and abstract concepts, are not devoid of real world applicability. In focusing on migration rights, theorists are keen to highlight the problems of the existing international regime. However, there is a clear distinction between developing theories which offer us moral principles to guide how we address real world problems, and compromising moral principles as a result of taking account of non-ideal realities. Carens describes his approach as 'political theory from the ground up' (2013, p.9), where real world problems and questions form the starting point for theorising moral principles. The knowledge that there may be 
obstacles to the achievement of these principles in the real world is not a reason to reject them as a guide for critiquing existing practices (see also Carens, 1996, on realistic morality).

Given the desire to develop theory with real world applicability, Carens' work features examples taken from existing practices of migration, and as a result, has considered conditions in the real world under which it might be appropriate to limit freedom of movement (according to Carens, there are very limited circumstances when public order may be threatened that restrictions on migration could be justified, on the basis that public order is necessary to protect all basic liberties). Other theorists have engaged with empirical studies of migration to similarly explore some of the implications of theory, or to defend its feasibility using examples of where it has been implemented, such as in the free movement regime of the European Union (EU). However, this engagement has tended to be at the level of general trends and patterns, or in relation to specific legal developments (Bloom, 2009; Casey, 2010; Hayter, 2004). The literature has tended not to engage with narratives of migration at the micro-level, and it is my intention in this article to highlight the significant value of this qualitative, discursive perspective to the open borders debate. In doing so, I do not intend to offer reasons to reject freedom of movement, in agreement with Carens that real world challenges should not lead us to reject guiding moral principles. ${ }^{\text {ii }}$ Rather, I aim to show how gaining greater insights into narratives of migration in everyday life and how they affect international migration practices is critical to understanding the nature of these challenges and how a robust theory of open borders could account for them.

\section{Narrative Research and Normative Theory}


An emergent literature is beginning to demonstrate the value of researching situated experiences of international phenomena for theorising in the broad field of applied international political theory, and as such this literature has strong salience for the argument presented in this article. This approach, which has been termed 'qualitative political theory' (Cabrera, 2009; 2010), challenges disciplinary orthodoxies through the production of normative accounts which are enriched with the narratives of those experiencing the phenomenon under consideration. Studies have employed such an approach to support the development of theory by exploring the implications of normative positions for the micro-level, lived contexts in which they would be enacted. In doing so, assumptions within such positions are challenged and potential obstacles to implementation identified (Ackerly, 2007; Brettschneider, 2002; van den Anker, 2008).

The process is iterative and reflexive, meaning that there is continuous interaction between theoretical development and insights gained in the field, with ongoing dialogue between researcher and researched. Qualitative political theory therefore challenges theorists to open up the process of theorisation and to reduce notions of objectivity - that somehow the theorist exists beyond the 'real world' to which their theory is intended to apply. This has much in common with the recent auto-ethnographic turn in international relations, where it is acknowledged that 'we cannot abstract ourselves from the world as academic convention pretends' (Edkins, 2013, p.282; see also Vrasti, 2010). It also means that expectations of what the narrative research will deliver are somewhat different, because the purpose is not generalisability of research findings but rather for the findings to act as a tool in an iterative process of theorisation.

It is not surprising that this methodology has gained particular traction within the field of international political theory. The distance between theorising and real world experience 
which often characterises normative work is intensified by the often global scale of the issue under consideration, and as such, qualitative data can be used by scholars to provide a 'human' dimension to theoretical accounts - research is regularly in story format in order to add weight to normative claims being made. The micro-level focus of such studies on the narratives associated with everyday experiences rather than on international elite discourses is also critical in reducing this distance. As Doty notes, '[o]ur studies often focus predominantly on highly visible and publicised global practices while every day, local enactments or experiences of ethics get lost or discounted in building theory' (Doty, 2006, p.55).

It is this particular approach to combining normative theory with research into the everyday narratives associated with global issues which is central to the argument put forward in this article, and which forms a methodological framing for the research to be discussed, specifically in relation to migration rights. Indeed, some existing studies have applied qualitative research into everyday experiences of migration to propose theories of migration rights (e.g. Cabrera, 2010; Doty, 2006). In this article, however, I want to draw particular attention to the kinds of insights offered to migration rights theory by researching specifically non-migrants as actors in international migration practices.

\section{Researching Non-Migrants}

Before exploring these insights, it is necessary to give some background detail on the relevance of researching non-migrants in international migration practices for migration rights theory. In 2013, over 231 million people had migrated to at least one country outside that of their birth (UN, 2013). The 'age of migration' (Castles and Miller, 2009) which is purported to have emerged over recent decades has led to greater complexity of migration practices. Migration may be permanent or transient, through a vast number of 
different migration routes, and may result in a wide range of different migration statuses. For example, of these 231 million migrants, the UN High Commissioner for Refugees (UNHCR, 2013) estimates that 16.7 million are refugees and 1.2 million are asylum seekers. Undocumented migration also accounts for a large amount, with approximately 11.7 million undocumented migrants in the USA alone (Preston, 2013). In many countries, this diversity within migration processes has given rise to a complex environment of 'superdiversity' as a result of the multi-layering of different types and patterns of migration over generations (Vertovec, 2007).

Yet, despite these trends, migration accounts for only $3.2 \%$ of the world's population. More developed countries in North America and Europe have tended to receive a greater proportion of migration as a result of global economic inequalities driving mass migration to more affluent nations - migrants accounted for $10.8 \%$ of the populations of more developed countries in 2013 (UN, 2013), although increasingly countries in the developing world are gaining very large migrant populations themselves particularly as a result of emergency migration. Migration also affects different towns, cities and regions within individual countries differently, with some acting as very large scale receiving communities over a long period of time, and others receiving much less - if any migration as a result of low employment opportunities and little existing diversity.

The migration rights literature has largely not considered non-migrants as actors in international migration practices. Reference to non-migrants is limited to the potential for 'antagonistic reactions... from current citizens' (Carens, 1987, p.259), which are largely dismissed as non-defensible reasons to restrict migration. Indeed, many large scale receiving countries display high levels of anti-migrant sentiment among nonmigrants (Kehrberg, 2007), and it stands to reason that such reactions could not form a 
reason to dismiss a guiding principle founded on individual moral equality, in the same way that the existence of sexism in the real world would not call into question the imperative to pursue equality for women from a moral perspective. However, rather than offering reasons to reject open borders, researching non-migrants offers an opportunity to develop more robust open borders theory as a result of examining whether and how the views of non-migrants, including anti-migrant sentiment, affect migration rights.

\section{Research Design}

Having set out the theoretical framing of the paper and introduced the methodological approach under consideration, I now move on to discuss the example research which I will use to illustrate the methodological argument of the paper. Research into nonmigrant narratives in English local communities explored narratives of migration among non-migrants at a local and everyday level, in order to deliver insights into how nonmigrant narratives impact on the realisation of the kinds of liberal equality-rooted migration rights common to the normative accounts described above. Non-migrant narratives are, of course, just one form of discourse which affects migration rights, and it may be argued that national and international political elites, as well as the media, have a far more significant role in shaping how migration is problematized, and that nonmigrants are only relevant insofar as they support or oppose migration policy developments. However, exploring non-elite narratives offers the scope to appreciate that these narratives are expressed beyond arenas of elite discourse, and to interrogate how their expression in everyday settings, and not just at the elite level, affects the realisation of migration rights. ${ }^{i i i}$

The study of narratives constructed by non-elite actors in everyday, local contexts in relation to migration practices is well established within a broadly sociological literature. 
Research has, for example, explored such topics as practices of border crossings and journeying (Bloch, Sigona and Zetter, 2011; Daley, 2009; Grill, 2012), the experience of arrival in a receiving country (Ehrkamp, 2005), the sense-making processes of forced migration (Eastmond, 2007), and experiences of departure, particularly in relation to the construction of 'illegality' and deportation in everyday life (de Genova, 2012; Khosravi, 2010). Studies of non-migrants have focused on everyday encounters between migrants and non-migrants in local community settings (Armbruster, Rolb and Meinhof, 2003; Valentine and Sadgrove, 2014; Herbert et al., 2008; Fox and Jones, 2013). Common to this literature is a methodological consensus that researching everyday experiences of largescale international trends offers the capacity to increase the depth of our understanding of migration.

The study described here to illustrate the central methodological argument of this article focused on non-migrant narratives of migration resulting specifically from the EU freedom of movement regime. A core right of citizenship of the EU, which is granted to all citizens of EU member states, is freedom of movement to live and work within any member state of the EU. The EU freedom of movement regime is based on a principle of non-discrimination, as the founding legislation states: 'within the scope of the application of the Treaties, and without prejudice to any special provisions contained therein, any discrimination on grounds of nationality shall be prohibited' (EU, 2010, article 12). This is very similar to the normative, moral equality based theories described earlier in the article, and as such identifying this context of migration from within the EU is useful for exploring the experience of free movement rights.

England was selected as a location for the research on the basis that it has received a large amount of migration from the EU (more so than any other part of the UK), and particularly 
since accession to the EU of ten Eastern European states (eight in 2004 and two in 2007).iv The chosen location for the research was Herefordshire, a rural county in the West Midlands region. Herefordshire had previously experienced very little migration but, since the accession of the Eastern European states, had received considerably higher amounts. Selecting this case meant that it was therefore possible to isolate narratives relating to specifically migration facilitated by the EU freedom of movement regime. This would be more difficult in other locations, such as large urban areas, with many different types of migration. Indeed, it is important to recognise that experiences of non-migrants will vary by place, and it cannot be expected that the insights gained from the Herefordshire case study would be similar to those found elsewhere. However, and in keeping with the wider qualitative political theory movement, the aim of the study was not to deliver empirical generalizability but rather to engage with individual situated experiences to support normative theorising through an iterative process between situated context and theoretical development.

The research involved open-ended, semi-structured interviews with 30 non-migrants within the case study area, with contacts gained through a snowball sampling technique. This was complemented with unobstructive observations of the area which included keeping a research diary and a photographic record, visits to some of the farms on which migrants were employed, and volunteering at a local migration charity. The aim of this approach, undertaken over the course of twelve months, was for the researcher to become embedded as much as possible into community life in the case study areas, to contextualise the non-migrant narratives elucidated in interviews. The research also involved interviews with some local elected representatives from nationalist parties; 
however, these are not discussed in this article as they are not relevant to the specific focus on everyday narratives.

\section{Everyday Narratives of Migration}

I now present an overview of the findings of this research, to illustrate the kinds of insights which can be delivered to normative theorists from everyday narratives research. There is not the scope to deliver a full analysis of the findings within the more methodological focus of the article; however, such an analysis is available elsewhere (anonymised). There are two particularly salient features of the construction of narratives of migration by nonmigrants to be drawn out for the purposes of this article.

The first critical insight is that the non-migrant narratives in the case study constructed migrants as workers, rather than as co-citizens of the EU with extensive rights to reside, work, raise a family and participate politically. A positive view of migration was apparent, but only insofar as migrants came to Herefordshire to work and contribute to the local economy. As one interviewee noted: 'I personally don't have any problem with the pickers themselves. I think they're very hardworking' (author interview, 2010), and another described in relation to the Eastern European migrant whom she had employed as a decorator: 'Pete the Pole. He’s working and he's contributing and presumably he's paying tax' (author interview, 2010).

This positive view of migration tended to be apparent, however, mainly when the migrant workers in Herefordshire were temporary. This was cast in contrast to elsewhere in the country, where the perception of the interviewees was that migration was more permanent and therefore having a more dramatic effect. As one interviewee reflected, 'I guess the other trend we might be concerned about is if this takes root like you've seen 
in other parts of the country, where the Eastern Europeans feel like staying' (author interview, 2010). Another commented, 'free movement of people coming here to work temporarily and that exchanged is fine... but I don't think they should stay here, if they haven't got work they should go back home' (author interview, 2010).

In this narrative of the migrant as (temporary) worker, the migrant is dehumanised as a commodity in the labour market and a contributor to the local economy. The deserving migrant is the one who works hard and makes a contribution, but as a result, migrants tend not to be viewed as anything more than (typically temporary) workers. This tendency to view migrants as temporary workers can be explained in part by the temporary nature of migration to Herefordshire, where the majority of migrants have typically worked in Herefordshire during peak seasons for agricultural labour, yet migrants are increasingly settling in the area on a more permanent basis and moving to jobs in other sectors. It also has much in common with research which has identified the existence of a 'no problem here' racism in the English countryside, where the perceived problems associated with migration and diversity are viewed as urban issues which exist elsewhere and do not affect the rural idyll (Chakraborti, 2010; Neal, 2002).

This narrative also has much in common with wider migration narratives which frame migrants as economic commodities of a neo-liberal global economy. Such a framing is apparent, for example, in the goals of the International Organisation for Migration (IOM) which aims to 'maximise economic growth potential' through its approach to migration management (Georgi, 2010), as well as through inter-governmental consultations on migration which have emphasised the good of the neo-liberal free market (Oelgemöller, 2011), and in the 'migration management' strategies of UK governments since the late 1990s which have emphasised the value of migration in relation to Britain's place in the 
global economy and the promotion of the national economic interest (Balch, 2009). Such narratives separate out the statuses of citizen and worker, and as such migrants are workers and commodities of the transnational labour market but do not have access to the kinds of rights and protections typically afforded by citizenship (Neilson and Rossiter, 2008; Overbeek, 2002).

Sitting alongside this narrative of the migrant as temporary worker, and the second key insight, is a form of 'banal' national loyalty. In contrast to the overtly nationalistic narratives of nationalist group members who formed a separate part of the research (see anonymised, ch.4), banal national loyalty is defined, drawing on Michael's Billig's seminal work on banal nationalism (1995), as an implicit assumption that membership and belonging are defined by membership of a specific national group. These unquestioned assumptions which define insider from outsider are reproduced in the narratives of citizens in their everyday lives.

This banal national loyalty was evident in non-migrant narratives covering a range of topics. For example, on the subject of employment opportunities beyond temporary work in the agricultural sector, one interviewee commented:

wherever you go, to a café, to a restaurant or wherever I would say seven or eight out of ten the staff there will be European migrants. Which is fine if they couldn't have got an English person but the way the economy's going at the moment, you have to think, I don't know, perhaps it's not right. (author interview, 2010)

On the subject of social housing, another noted: 
You know and you hear of sort of young children, not young children young adults, that are trying to move in together, rent somewhere, there's nothing cheap to rent because all the Polish, Lithuanians, whatever are taking them. (author interview, 2010)

It was evident again in discussion of healthcare services, as one interviewee discussed the availability of hospital beds:

It's when people, when there aren't any beds, that's... it's the nature of any country, if you've got foreign people who are in the country as migrants then it, if there aren't any beds and there are other people there... if that was the case I think if you've got British or whatever then you would have priority over a migrant who is visiting from, you know, for whatever reasons. (author interview, 2010)

A banal sense of national loyalty also appeared in narratives on such topics as education (particularly in terms of the availability of school places), and the availability of social welfare benefits, where migrants were cast as making excessive demands on the welfare state and failing to contribute to the economy. The scapegoating of Eastern Europeans as 'benefits scroungers' making unfair use of the welfare state is a common narrative in public and political discourses about migration in the UK more generally (Balabanova and Balch, 2010; Wilkinson, 2014).

Stories of personal experience were additionally used to infuse this narrative with everyday meaning, such as in the case of a mother with two young children:

I certainly know at ${ }^{* * * \prime}$ s and ${ }^{* * * '}$ s school because they go to a Catholic school, ***** School, and there's a lot of Eastern Europeans there because of the 
Catholic, they are able to get straight in there, whereas there's a waiting list for people that have been born and bred in Hereford. But the Eastern Europeans seem to be able to get straight in, don't they. (author interview, 2010)

Similarly, another interviewee reflected on their own knowledge of an incident where a migrant family had been prioritised over a non-migrant family in the allocation of social housing. She described how 'they were doing the maisonettes next to her, two blocks of maisonettes, and they were allocated for migrant workers. Now this is where you get the trouble' (author interview, 2010). It is this drawing on local, everyday and personal stories which adds to their power in micro-level contexts.

\section{Between Transnationalism and National Belonging}

In the case of this research, the exploration of these two critical insights from the research contributed, through the iterative and reflexive process previously described, to theoretical development by showing how the realisation of migration rights is affected at an everyday level. The insights show how the everyday narratives of non-migrants in Herefordshire construct migration as temporary and economically motivated, cast the migrant as a commodity of the labour market, and implicitly assume the validity of national loyalty as a principle guiding access to wealth, opportunities, public services and social welfare benefits.

The construction of the migrant as a unit of the transnational economy in this research is also actively reinforced by parallel narratives of national belonging which predicate membership on a sense of belonging to the nation and thereby casts migrants as valuable insofar as they support the national economy, but not as co-members with justified rights 
claims. As a result, the development of these narratives in the case study normalised and legitimised the precarity of the migrant worker at the micro-level, focusing on the economic value of a temporary and flexible workforce while overlooking justified rights claims, the necessity of social attachment and the intimate impact of precarity on, for example, family life (Anderson, 2010; Robertson, 2014). These narratives were anchored within the experience of rural community life in this particular local context, and so while they are not generalizable beyond this context, examining and reflecting on these insights offered the scope for theoretical development on the basis that reflecting on the way those interviewed for the case study research spoke about migration gives a sense of some of the potential barriers to realising migration rights at the local level.

The construction of these narratives in this everyday context is significant in understanding the barriers to fully realising migration rights. In constructing the meaning of migration practices in everyday life, the research reveals how these narratives shape the experience of those practices. For example, local elites in the case study reported a lack of political debate locally concerning how to shape public services to best meet the needs of a changing demographic as a result of migration (a lack which is also mirrored at the national level, where policy is being developed to limit EU migrants' access to key public services). In the case study, there was no discussion of introducing or shaping services for new migrants, and again this is mirrored at the national level where what little support did exist (the Migration Impacts Fund) was quietly abolished in 2010 without any resistance. Dominant non-migrant narratives in Herefordshire separated out migrants as a temporary, guest population in our country ('they're still foreign people as such in our country' - author interview, 2010), and it is 
only we who have rights claims and are deserving of access to public services and other social goods.

Therefore, there is no general sense of support for addressing the public service challenges which accompany the introduction of a new population, or even to incorporate migrants into the life of the community. One local elite described how migrants are rendered 'invisible people' (author interview, 2010) by these complex processes of exclusion from the social construction of rural community life. This invisibility was evident during the research, where the visual appearance of the communities, their shops and other services for example, had not changed at all as a result of migration and it was generally viewed that, as long as everything stayed the same, there would not be a problem. One local elite described this as follows, 'I think... people are most concerned about keeping the fabric of the town exactly as it always has been' (author interview, 2010).

\section{Theorising Open Borders (2)}

This analysis offers important insights for the migration rights literature described earlier in the paper, as indeed was its function as a tool of theoretical development. In this final substantive section, I reflect on the normative developments resulting from these insights to demonstrate the value of this approach to incorporating such research into normative theorising about migration rights.

As noted earlier in the paper, scholars advocate open borders on the basis that liberal moral equality demands it. Birthplace is argued to be a morally arbitrary criterion and therefore states must recognise the equality of all individuals despite their place of birth, resulting in the recognition of a right to migrate. This is the core goal of implementing 
freedom of movement, which serves to redress inequalities in access to wealth and opportunities. Yet the research discussed here has suggested that everyday constructions of migration can affect the realisation of this equality of opportunity. Seemingly banal narratives, in the case study examined, serve to exclude migrants from political debate, from public service provision, and - less tangibly - from community life. They become invisible, performing work in the service of the transnational neo-liberal economy, but unable to transcend the constraints of national belonging which serve to exclude them, and as a result, limit their ability to develop and fulfil a life plan, including developing a social and family life (see also 0’Reilly, 2007).

For open borders theory, therefore, this analysis highlights that, in agreement with Bloom (2009, p.240), '[f]reedom to move without accompanying support and welcome is not the freedom Carens envisages'. Bloom was referring to the domestic economic injustices that migrants are subjected to which reduce the achievement of the equality of opportunity goal. But this research also highlights that the same can be said of some of the less tangible aspects of receiving community life.

As a result, drawing on this analysis of everyday narratives research in normative theoretical development allows for a questioning of the defensibility of articulating a theory of migration rights which does not also address the exclusionary effects of persistent forms of national identity. These forms of nationalism may seem banal and non-dangerous in comparison to some of the more ethno-nationalist, exclusionary rhetoric of nationalist political parties and movements, yet in the research they had very real effects on the exclusion of migrants in host communities. While it isn't necessarily the case that these findings would be replicated in exactly the same way everywhere, exposing the everyday dynamics of one particular migration-receiving community has 
suggested the importance of developing theory which is able to account for the challenges associated with nationalism arising for the implementation of migration rights in these local level settings.

Insights from this research, therefore, suggest that in arguing for unrestricted migration rights, theorists should also engage in normative work towards a post-national form of political integration which reframes citizenship and belonging within an interpretation of universal human rights rather than national belonging (cf. Habermas, 1995; Müller, 2007). This is because the open borders arguments of theorists such as Joseph Carens are challenged by persistent nationalism, and so as a result the equality of opportunity goal of freedom of movement may only be realised if open borders theorists are prepared to move out of the dominant nation-state framework to explore alternatives.

Arguing for freedom of movement as well as for a more 'post-national' form of political integration may offer a better means of securing the goals of freedom of movement while addressing the obstacles presented by persistent national loyalty. There are, of course, challenges in realising such post-national political integration; not least, the imposition of a new form of identity may be as unpopular for local communities as open borders migration. It is for this reason that I have, elsewhere, argued in favour of a postnationalism from the 'bottom up' (reference anonymised). It is not the purpose of this paper to defend such a position, but rather to highlight it as the outcome of normative theorising using insights from narratives drawn from everyday life. Similarly, it may also be the case that migration rights are better realised where they are accompanied by a normative account aimed at addressing global social inequalities which preserve the precarity of the migrant worker as economic commodity.

\section{Conclusion}


The purpose of this article was to offer a methodological argument in favour of incorporating research on the everyday narratives of non-migrants into the normative theorisation of migration rights. The article has done so by exploring the kinds of insights which can be delivered through the incorporation of narrative research into normative theorising about migration rights, offering research into everyday narratives of nonmigrants found in an English rural community as an illustrative example.

The article set out the core migration rights literature which has tended not to engage with research into everyday narratives and then, through the example of research into the everyday narratives of non-migrants in an English rural community, highlighted how such research can provide valuable insights for use in theorising migration rights. Specifically, non-elite and banal narratives were found to construct obstacles to the full realisation of the equal opportunity goal of unrestricted migration in this context, which led to the claim that open borders migration rights cannot be robustly theorised in isolation and suggested the importance of theorising open borders alongside wider theories of post-national political integration which offer the scope to imagine political community beyond the nation-state framework which acts to restrict the full realisation of free movement rights.

At a broad level, the article has demonstrated that engaging with research into everyday narratives offers important opportunities to engage in normative theoretical development from the bottom up, engaging with the ideas and claims of ordinary people to fully appreciate the nature of the issue to be addressed and using this to develop robust moral principles. The research presented focused only on one particular case study and was not intended to claim generalisability, but rather to show how engaging with everyday experience of large scale international phenomena can aid the work on the 
theorist in developing a robust account of migration rights, by highlighted how the lived experience of international and global issues are affected by phenomena only observable at an everyday level.

There are grounds for some ontological debate about how appropriate the use of everyday narrative research is in relation to normative theoretical development which is intended to have more universalistic appeal. Yet in drawing on everyday narrative research in normative theorising, the purpose is not to 'prove' the existence of some social phenomenon but rather to expose and support the researcher's reflexive and iterative process of theorisation. As a result, the burden of proof resting on everyday narrative research in this field is significantly dampened, as the subjectivity of the theorist and their position on the inside of the phenomenon on which they are working are embraced. The use of everyday narrative research in normative theorising may, therefore and perhaps surprisingly given its claims to universalism, be less contentious than in other, more empirical fields of political science.

\section{Acknowledgments}

I am grateful to Liam Stanley, Richard Jackson, Tendayi Bloom and the anonymous reviewers of this journal for helpful comments on previous drafts. I am also grateful to colleagues who attended the 'Borders and Boundaries' research seminar at Aston University on $25^{\text {th }}$ February 2015 for insightful and productive discussion on an earlier version of the article.

\section{About the Author}

Katherine Tonkiss is a Lecturer in Sociology and Policy at the School of Languages and Social Sciences, Aston University. She is interested in the ethics, practice and policy of 
immigration and citizenship. Her book, Migration and Identity in a Post-National World, was published in 2013. She is currently working on a British Academy-funded project examining migration policy-making in the UK and Australia. Contact: k.tonkiss@aston.ac.uk.

\section{References}

Abizadeh, A. (2008) 'Democratic Theory and Border Coercion: No Right to Unilaterally Control Your Own Borders, Political Theory, 36 (1), pp.37-65.

Ackerly, B.A. (2007) Universal Human Rights in a World of Difference, Cambridge: Cambridge University Press.

Anderson, B. (2010) 'Migration, Immigration Controls and the Fashioning of Precarious Workers', Work Employment Society, 24 (2), pp.300-317.

Armbruster, H, Rolb, C, and Meinhof, U.H. (2003) 'Imagining Europe: Everyday Narratives in European Border Communities', Journal of Ethnic and Migration Studies, 29 (5), pp.885899.

Balabanova, E. and Balch, A. (2010) 'Sending and Receiving: The Ethical Framing of IntraEU Migration in the European Press', European Journal of Communication, 25 (4), pp.382397.

Balch, A. (2009) 'Labour and Epistemic Communities: The Case of 'Managed Migration' in the UK', British Journal of Politics and International Relations, 11, pp.613-633.

Billig, M. (1995) Banal Nationalism, London: Sage. 
Bloch, A, Sigona, N, and Zetter, R. (2011) 'Migration Routes and Strategies Among Young Undocumented Migrants in England: A Qualitative Perspective', Ethnic and Racial Studies, 34 (8), pp.1286-1302.

Bloom, T. (2009) 'Just Open Borders? Examining Joseph Carens' Open Borders Argument in Light of a Case Study of Recent Somali Migrants to the UK', Journal of Global Ethics, 5 (3), pp.231-243.

Brettschneider, M. (2002) Democratic Theorising from the Margins, Philadelphia: Temple University Press.

Cabrera, L. (2009) 'An Archaeology of Borders: Qualitative Political Theory as a Tool in Addressing Moral Distance', Journal of Global Ethics, 5 (2), pp.109-123.

Cabrera, L. (2010) The Practice of Global Citizenship, Cambridge: Cambridge University Press.

Carens, J. (1987) 'Aliens and Citizens: The Case for Open Borders', The Review of Politics, 49 (2), pp.251-273.

Carens, J. (1996) 'Realistic and Idealistic Approaches to the Ethics of Migration', International Migration Review, 30 (1), pp.156-170.

Carens, J. (2013) The Ethics of Immigration, Oxford: Oxford University Press.

Casey, L.P. (2010) 'Open Borders: Absurd Chimera or Inevitable Future Policy?', International Migration, 48 (5), pp.14-62.

Castles, D, and Miller, M.J. (2009) The Age of Migration: International Population Movements in the Modern World, Basingstoke: Palgrave Macmillan. 
Chakraborti, N. (2010) 'Beyond Passive Apartheid? Developing Policy and Research Agendas on Rural Racism in Britain', Journal of Ethnic and Migration Studies, 36 (3), pp.501-17.

Cole, P. (2000) Philosophies of Exclusion: Liberal Political Theory and Immigration, Edinburgh: Edinburgh University Press.

Daley, C. (2009) 'Exploring Community Connections: Community Cohesion and Refugee Integration at a Local Level, Community Development Journal, 44 (2), pp.158-171.

De Genova, N.P. (2002) 'Migrant 'Illegality' and Deportability in Everyday Life', Annual Review of Anthropology, 31, 419-447.

De Haas, H. (2005) 'Migration and Development: A Theoretical Perspective', International Migration Review, 44 (1), pp.227-264.

Doty, R.L. (2006) 'Fronteras Compasivas and the Ethics of Unconditional Hospitality', Millennium: Journal of International Studies, 35 (1), pp.53-74.

Dummett, M. (2004) 'Immigration', Res Publica, 10 (2), pp.115-122.

Eastmond, M. (2007) 'Stories as Lived Experience: Narratives in Forced Migration Research', Journal of Refugee Studies, 20 (2), pp.248-264.

Edkins, J. (2013) 'Novel Writing in International Relations: Openings for a Creative Practice', Security Dialogue, 44 (4), pp.281-297.

Ehrkamp, P. (2005) 'Placing Identities: Transnational Practices and Local Attachments of Turkish Immigrants in Germany', Journal of Ethnic and Migration Studies, 31 (2), pp.345364. 
European Union [EU] (2010) 'Consolidated Versions of the Treaty of European Union and the Treaty on the Functioning of the European Union', Official Journal of the European Union, 53 (2010/C 83/01).

Fox, J.E, and Jones, D. (2013) 'Migration, Everyday Life and the Ethnicity Bias', Ethnicities, $13(4)$, pp.385-400.

Georgi, F. (2010) 'For the Benefit of Some: The International Organisation for Migration and its Global Migration Management', in Geiger, M, and Pecoud, A. (eds.) The Politics of International Migration Management, Basingstoke: Palgrave Macmillan, pp.45-72.

Grill, J. (2012) “Going Up to England': Exploring Mobilities Among Roma from Eastern Slovakia', Journal of Ethnic and Migration Studies, 38 (8), pp.1269-1287.

Habermas, J. (1995) 'Citizenship and National Identity: Some Reflections on the Future of Europe', in Beiner, R. (ed.) Theorising Citizenship, Albany: SUNY Press, pp.255-82.

Hayter, T. (2004) Open Borders: The Case Against Immigration Controls, London: Pluto.

Herbert, J, May, J, Wills, J, Datta, K, Evans, T, and McIlwane, C. (2008) ‘Multicultural Living? Experiences of Everyday Racism Among Ghanian Migrants in London', Urban and Regional Studies, 15 (2), pp.103-117.

Kehrberg, J.E. (2007) 'Public Opinion on Immigration in Western Europe: Economics, Tolerance and Exposure', Comparative European Politics, 6, pp.264-281.

Khosravi, S. (2010) Illegal Traveller, Basingstoke: Palgrave Macmillan.

Miller, D. (2000) Citizenship and National Identity, Cambridge: Polity Press.

Müller, J.W. (2007) Constitutional Patriotism, Princeton: Princeton University Press. 
Neal, S. (2002) 'Rural Landscapes, Representations and Racism: Examining Multicultural Citizenship and Policy-making in the English Countryside', Ethnic and Racial Studies, 25 (3), pp.442-61.

Neilson, B, and Rossiter, N. (2008) 'Precarity as a Political Concept, or, Fordism as Exception', Theory Culture Society, 25, pp.51-73.

Oelgemöller, C. (2011) 'Informal Plurilateralism: The Impossibility of Multilateralism in the Steering of Migration', British Journal of Politics and International Relations, 13, pp.110-126.

O’Reilly, K. (2007) 'Intra-European Migration and Mobility - enclosure dialectic', Sociology, 41 (2), pp.277-293.

Overbeek, H. (2002) 'Globalisation and Governance: Contradictions of Neo-Liberal Migration Management', HWWA Discussion Paper, no.174.

Preston, J. (2013) 'Number of Illegal Immigrants in the US May Be on the Rise Again, Estimates Say. The New York Times [online], 24th September. Available from: http://www.nytimes.com/2013/09/24/us/immigrant-population-shows-signs-ofgrowth-estimates-show.html (Accessed 3 ${ }^{\text {rd }}$ February 2015).

Rawls, J. (1999 [1979]) A Theory of Justice, Cambridge, MA: Harvard University Press.

Robertson, S. (2014) 'Noncitizens in Contemporary Australia: Consumption, Contract and Resistance'. Paper presented at the ECPR general conference, $4^{\text {th }}-6^{\text {th }}$ September, Glasgow. Rubio-Marin, R. (2000) Immigration as a Democratic Challenge, Cambridge: Cambridge University Press.

Schachar, A. (2009) The Birthright Lottery, Cambridge, MA: Harvard University Press. 
United Nations [UN] (2013) Total International Migrant Stock [online]. United Nations Population Division. Available from http://www.un.org/en/development/desa/population/migration/data/index.shtml [accessed 3rd February 2015].

United Nations High Commissioner for Refugees [UNHCR] (2013) War's Human Cost: UNHCR Global Trends 2013 [online]. UNHCR. Available from: http://www.unhcr.org/5399a14f9.html [accessed 3rd February 2015].

Valentine, G, and Sadgrove, J. (2014) 'Biographical Narratives of Encounter: The Significance of Mobility and Emplacement in Shaping Attitudes Towards Difference', Urban Studies, 51 (9), pp.1979-1994.

Van den Anker, C. (2008) 'Human Rights in Iran: The Ethnography of 'Others' and Global Political Theory', Journal of International Political Theory, 4 (2), pp.265-282.

Verlinden (2010) 'Free Movement? On the Liberal Impasse in Coping With the Immigration Dilemma', Journal of International Political Theory, 6 (1), pp.51-72.

Vertovec, S. (2007) 'Superdiversity and its Implications', Ethnic and Racial Studies, 30 (6), pp.1024-1054.

Vrasti, W. (2010) 'Dr Strangelove, or How I Learned to Stop Worrying About Methodology and Love Writing', Millennium: Journal of International Studies, 39 (1), pp.79-88.

Walzer, M. (2008) 'The Distribution of Membership', in Pogge, T, and Moellendorf, D. (eds.) Global Justice: Seminal Essays: Global Responsibilities Volume 1, Minnesota: Paragon House, pp.145-77. 
Wilkinson, M. (2014) 'Demonising 'The Other': British Government Complicity in the

Exploitation, Social Exclusion and Vilification of New Migrant Workers', Citizenship

Studies, 18 (5), pp.499-515.

\footnotetext{
i The binary definition of migrant and non-migrant is somewhat problematic. In practice, these categories are blurred as a result of individuals holding different statuses at different points in time (cf. de Haas, 2010). Any objective measure of status, such as through citizenship status, would be flawed because citizenship may be gained later in life following migration. Equally, the 'non-migrant' category may overlook the histories of migration which characterise almost all families and essentialise the mobility and fixity of different populations. However, for the purposes of this article it is useful to differentiate between those with experience of migration and those without. Therefore, I define non-migrant in terms of the self-identification of individuals as non-migrants, and as having no personal experience of migrating.

ii The scope of this article cannot extend to consider whether there are normative reasons to reject open borders theories, as others have articulated for example in relation to the moral significance of borders and the rights of self-determining communities to democratically decide on their own border policy (cf. Miller, 2000; Walzer, 2008). Its starting point, rather, is with the acceptance of arguments in favour of freedom of movement on the basis of individual moral equality. I have considered the defensibility of these arguments, as well as dominant critiques, elsewhere (reference anonymised).

iii See also Fox and Jones (2013) for a similar exploration of how individuals actively construct difference through everyday practices.

iv In 2004, the so-called 'A8' states acceded to the EU with no restrictions placed on migration of citizens of those states to the UK. This was unlike the majority of other EU member-states which imposed some transitional restrictions over fears about the scale of migration from the new states (and was the main motivation for the selection of the UK as the member-state location for this research). These A8 states were the Czech Republic, Estonia, Hungary, Latvia, Lithuania, Poland, Slovakia and Slovenia. In 2010, two further states (the 'A2' states - Bulgaria and Romania) acceded to the EU, and this time the UK did place some restrictions on mobility, particularly for low-skilled workers who could only move within the guidelines of specific employment quota schemes. These transitional arrangements ended in 2014.
} 